\title{
Turkish Contribution to Journal of Neurosurgery and Acta Neurochirurgica
}

\author{
Nur ALTINORS, Serhat COMERT, Erkin SONMEZ, Faruk ALTINEL \\ Baskent University, Department of Neurosurgery, Ankara, Turkey
}

\section{ABSTRACT}

AIM: To evaluate the contribution of Turkish scientists to four journals published by Journal of Neurosurgery (JNS) Publishing Group and to Acta Neurochirurgica (AN) and to its Supplement (ANS).

MATERIAL and METHODS: We reviewed every issue of those journals to December 2015 for the total number of articles, articles produced from studies performed entirely in Turkey, and for publications overseas co-authored by the Turkish scientists using the websites of these journals. Citations were searched using "Web of Science" and "Google Scholar" databases.

RESULTS: The total number of articles published was 19822 for JNS, 3227 for JNS Spine, 2526 for JNS Pediatrics and 2997 for Neurosurgical Focus. Turkish contribution was 556 articles. 337 (60.61\%) articles were the products of studies performed entirely in Turkey, while 219 (39.38\%) articles came from overseas, co-authored by Turkish scientists. Overall contribution was $1.94 \%$. A total of 6469 articles were published in AN. 340 papers were the products of studies performed entirely in Turkey. Turkish scientists working overseas co-authored 37 articles. Total contribution was 377 articles (5.82\%). 4134 papers had been published in ANS. Contribution was 69 articles (1.66\%).

CONCLUSION: Turkish contribution to these journals has started late. The gap has been compensated with publications in the last two decades. Manuscripts of higher scientific level with greater number of citations are needed to increase Turkish contribution to such journals.

KEYWORDS: Acta neurochirurgica, Acta neurochirurgica supplement, Citation, Journal of neurosurgery, Neurosurgery, Scientific publication, Turkey

\section{INTRODUCTION}

$\mathrm{T}$ The Latin proverb "Verba volant, scripta manent" and the more widely known cliché "Publish or perish" underline the importance and need to put knowledge into written, visible form for storage and dissemination. The latter has been modified as "publish, be cited or perish" to emphasize the importance of being cited (16).

The total number of publications, their variety, the impact factor of the journals where they are published and total number of citations are the classical parameters for evaluation of scientific works.

A recent concept, h-index introduced by Hirsch (18) in 2005 , have gained wide acceptance and usage. The $h$-index tries to evaluate the number of papers published by an author, their impact on the field, and the longevity of the impact.

The hypothesis of this study was that the contribution of Turkish scientists to journals published by Journal of Neurosurgery Publishing Group (JNSPG), to Acta Neurochirurgica (AN) and to Acta Neurochirurgica Supplement (ANS) would give an idea about the level of Turkish Neurosurgical community in the international arena.

We believe that information derived from this study could identify positive trends and developments as well as deficiencies and areas in need of improvement. It may also pave the way for further studies. 


\section{MATERIAL and METHODS}

Every issue of the Journal of Neurosurgery (JNS), JNS: Spine, JNS: Pediatrics and Neurosurgical Focus (NF) was reviewed by the senior author (NA) from their first issue to December 2015 issues inclusive using the" thejns.org" web site. All manuscripts were screened for their author, institution and country affiliation and were counted. Papers that were products of the studies performed entirely in Turkey formed the first category. The second group included the manuscripts published overseas, co-authored by Turkish scientists. If the names and family names of the authors in this second group were certainly Turkish, it was considered as "Turkish contribution" regardless of the author's institutional affiliation or second nationality if present. In instances where there was suspicion about the nationality of the author (e.g. similar names in Turkish, Arabic or Persian) then the curriculum vitae (CV) and background of the author were searched in different sources to find out the original nationality of the author.

Headings of "to the editor", "response", "introduction", "erratum", "editor's perspective" and "correction" were counted. The articles were analyzed according to their variety. Percentage of each variety of manuscript and total percentage of Turkish contribution to each of the four journals were calculated.

The manuscripts published in JNS were analyzed chronologically to observe any evidence of decline or progress of Turkish contribution. The citations to manuscripts were searched using the web of science with the key words of "Turkey" and "Journal of Neurosurgery". The findings derived from this search was cross checked against the search made in Google Scholar. A top citation ranking list was composed by combining the number of citations found in the domain of these two sources. The subjects and the variety of the manuscripts on this citation ranking list were also analyzed.

All past issues of AN, from its first issue in 1950, are stored on its Web site "www.springer.com/medicine/surgery/journal/ 7 ". This is a very reliable source and the senior author (NA) screened all issues of AN up to December 2015 on that site. The total number of articles in each issue was counted and recorded. Each article title and list of authors was carefully read to identify articles produced in Turkey. If a Turkish scientist had co-authored in a study performed overseas, this was also considered a Turkish contribution and recorded. The number of articles that appeared in five different languages was counted and recorded up to Volume 43 (1-2, March 1978). The results were cross-checked with the findings obtained from a PubMed search using the key words "Turkey" and "Acta Neurochirurgica".

The issues of ANS were supplied by the library staff of Başkent University. The number of issues, number of articles, articles produced in Turkey and contribution of Turkish scientists working overseas were screened by the senior author (NA) in the same manner as the issues of AN were reviewed. The results were cross checked by the results obtained from PubMed search given the key words "Turkey" and "Acta Neurochirurgica Supplement".
The citations to those articles, defined as Turkish contribution, published in AN and ANS were searched using "Web of Science" and "Google Scholar" by the second author (SC). The manuscripts were listed according to the number of citations they received, and top ranking articles were determined. The papers were further analyzed according to their kind.

\section{RESULTS}

\section{Journal of Neurosurgery}

Our review revealed that the first publication from Turkey appeared in 1975, 31 years after the publication of the first issue of JNS. During the years 1955-1975 there were publications where Turkish doctors working abroad, mainly United States of America (USA), contributed as the first or the second author. The first Turkish neurosurgeon who published an article in JNS was Dr. Gokay. He reported a case study in 1955 while working in USA (14). Most of those individuals became the pioneers of neurosurgery after their return to homeland.

Our search of the website "thejns.org" revealed that 757 issues of JNS, 163 issues of JNS: Spine, 134 issues of JNS: Pediatrics and 232 issues of Neurosurgical Focus from their first issues to December 2015 issue inclusive, were published. Total number of articles published were 19822 for JNS, 3227 for JNS: Spine, 2526 for JNS: Pediatrics and 2997 for Neurosurgical Focus (Table I).

Turkish contribution consisted a total of 556 articles. Of these $337(60.61 \%)$ were performed entirely in Turkey whereas 219 (39.38\%) studies were done abroad co-authored by Turkish scientists, mainly in the USA. The analysis of the homeland articles revealed that there were $110(32.64 \%)$ case reports/ case illustrations, $68(20.17 \%)$ clinical articles, 46 (13.64\%) experimental/laboratory studies, 13 (3.85\%) technical notes. There were $57(16.91 \%)$ "to the editor" and $30(8.90 \%)$ "response" headings.

The breakdown of the abroad studies showed that case reports/case illustrations to be $11.87 \%(26 / 219)$ and clinical articles to account for $47.48 \%$ (104/219). Experimental/ laboratory studies composed $15.98 \%$ (35/219) and technical notes were found to be $6.84 \%$ (15/219). The percentage of "to the editor" and "response" significantly decreased to $2.73 \%$ $(6 / 219)$ and $4.10 \%(9 / 219)$ respectively.

Table II illustrates the variety of the publications both from Turkey and abroad with Turkish contribution.

We reviewed Google Scholar and Web of Science for citations. There was considerable quantitative difference between these data bases, but ranking seemed to be similar. Analysis of the citations revealed that the top three studies in the ranking list were anatomical studies performed by Dr. Türe as the first author $(48,49)$ and by Dr. Çekirge as the second author (31), reporting their experience in endovascular treatment of large and giant intracranial aneurysms. All three studies were performed abroad. 
The articles ranking fourth (5), fifth (13) and sixth (24) according to the figures of Google Scholar were performed in Turkey. Two of them dealt with intracranial hydatid cysts $(5,24)$. The manuscript by Ersahin et al. (13) was about split malformations in pediatric age group. Four of the remaining six articles in the top 12 most cited list were performed in Turkey; two of them were about intracranial hydatid cysts $(32,45)$ while the other two reported their experience with endovascular treatment of intracranial aneurysms and arteriovenous malformations $(40,52)$. One of the two studies performed abroad was an anatomical study (12) and the other discussed temporal lobe surgery (51).

The most cited top 12 articles published in journals of JNSPG, using the Google scholar and web of science are listed on Table III.

The distribution of papers published in JNS over time was analyzed. Manuscripts originating from Turkey and papers produced abroad with Turkish contribution both showed climax in the first decade of $21^{\text {st }}$ century. There was no contribution from Turkey during 1944-1969 period while the manuscripts produced abroad with Turkish contribution was only $7.60 \%$ in the same period (Table IV).

\section{Acta Neurochirurgica}

Our search revealed that from 1950 to December 2015, 546 issues of AN were published. Those issues contained 6469 articles. There were 340 papers produced entirely in Turkey and Turkish scientists working temporarily or permanently overseas have co-authored 37 articles. The total Turkish contribution was 377 articles (5.82\%). Analysis of ANS showed that in the same period, 118 issues were published containing 4134 papers. There were 30 articles from Turkey $(0.7 \%)$ while Turkish scientists working abroad co-authored 39 articles (0.94\%); the overall Turkish contribution amounted to 69 articles $(1.66 \%)$.

Table I: Total Number of Issues of Four Journals of JNSPG from Their First Issues up to December 2015 Inclusive, the Total Numbers of Articles Published in These Journals, the Numbers and Percentage of Turkish Contributions

\begin{tabular}{lcccc}
\hline \multicolumn{1}{c}{ Journals } & Total issues & Total articles & $\begin{array}{c}\text { Turkish contribution } \\
\text { no. of articles }\end{array}$ & $\begin{array}{c}\text { \% of Turkish } \\
\text { contribution }\end{array}$ \\
\hline Journal of Neurosurgery & 757 & 19822 & 263 & 1.32 \\
\hline SPINE & 163 & 3227 & 155 & 4.83 \\
\hline PEDIATRICS & 134 & 2526 & 65 & 2.59 \\
\hline Neurosurgical Focus & 232 & 2997 & 73 & 2.46 \\
\hline Overall & 1286 & 28572 & 556 & 1.94 \\
\hline
\end{tabular}

Table II: Types of Articles and the Proportion Published by Turkish Authors in the Four Journals of JNSPG

\begin{tabular}{lccccccccc}
\hline Article types & $\begin{array}{c}\text { JNS } \\
\text { Turkey }\end{array}$ & $\begin{array}{c}\text { JNS } \\
\text { Abroad }\end{array}$ & $\begin{array}{c}\text { Spine } \\
\text { Turkey }\end{array}$ & $\begin{array}{c}\text { Spine } \\
\text { Abroad }\end{array}$ & $\begin{array}{c}\text { Pediatrics } \\
\text { Turkey }\end{array}$ & $\begin{array}{c}\text { Pediatrics } \\
\text { Abroad }\end{array}$ & $\begin{array}{c}\text { N.Focus } \\
\text { Turkey }\end{array}$ & $\begin{array}{c}\text { N.Focus } \\
\text { Abroad }\end{array}$ & Total \\
\hline Case report & 40 & 12 & 27 & 9 & 33 & 5 & 10 & 0 & 136 \\
\hline To the Editor & 36 & 3 & 12 & 2 & 6 & 0 & 3 & 1 & 63 \\
\hline Clinical article & 31 & 50 & 18 & 19 & 6 & 6 & 13 & 29 & 172 \\
\hline Exp./lab. & 15 & 21 & 29 & 10 & 1 & 3 & 1 & 1 & 81 \\
\hline Response & 13 & 6 & 12 & 2 & 1 & 1 & 4 & 0 & 39 \\
\hline Technical note & 5 & 12 & 5 & 1 & 1 & 0 & 2 & 2 & 28 \\
\hline Anatomy & 2 & 9 & 2 & 1 & 0 & 0 & 1 & 1 & 16 \\
\hline Elec.neur.phy & 1 & 0 & 0 & 0 & 0 & 0 & 0 & 0 & 1 \\
\hline History & 1 & 3 & 2 & 0 & 2 & 0 & 0 & 2 & 10 \\
\hline Erratum & 0 & 1 & 1 & 0 & 0 & 0 & 0 & 0 & 2 \\
\hline Review & 0 & 1 & 1 & 0 & 0 & 0 & 0 & 1 & 3 \\
\hline Biomech. & 0 & 0 & 0 & 2 & 0 & 0 & 0 & 2 & 4 \\
\hline Commentary & 0 & 1 & 0 & 0 & 0 & 0 & 0 & 0 & 1 \\
\hline Total & 144 & 119 & 109 & 46 & 50 & 15 & 34 & 39 & 556 \\
\hline
\end{tabular}


Analysis of the articles categories revealed 109 case reports (32.05\%), 94 experimental studies (27.64\%), 71 clinical series $(20.88 \%)$ and 26 "letters to the editor" (7.64\%). Full details appear in Table V.

The contributions of Turkish doctors working abroad included 11 case reports, 11 clinical series, six animal experiments, four cadaveric anatomy studies, two technical notes, two review articles and one" letter to the editor". Almost half of these contributions came from the United States (19 articles) followed by Germany (7 articles), France and Switzerland (four articles each) and one article from Japan, Netherlands and Canada. In the case of 31 manuscripts, a Turkish scientist was the first author, in five articles second author and in one article third author.

\section{DISCUSSION}

\section{History of Journal of Neurosurgery}

JNS is an outstanding journal in neurosurgery and closely related fields, and has worldwide subscribers, readers and contributors.
The JNS was initiated in 1944 as a publication of the Harvey Cushing Society and afterwards came under the control of the Board of Directors of the American Association of Neurological Surgeons (AANS) (3). Alfonso Asenjo and John F. Fulton were the founding fathers of the journal. Dr. Asenjo was working as the head of the Cushing Neurosurgical Pavilion at Santiago, Chile while Dr. Fulton was in Yale. They published an memorandum on November 2, 1943 announcing Journal of Neurosurgery Under the Auspices of the Harvey Cushing Society. The first issue arrived in New Haven on March 17, 1944 (10). Gilbert Horrax was appointed as the first chairman of the Editorial Board while Louise Eisenhardt as the managing editor (29). The journal was initially published bimonthly and it became monthly beginning with 1962.

The JNS: Spine started its publication in 1999 as a quarterly supplement to JNS and it eventually became bimonthly in 2002. Likewise the JNS: Pediatrics began publication as quarterly in 2004 and next year became bimonthly.

The newest publication was Neurosurgical Focus beginning publication in 1996 as bimonthly and becoming monthly the

Table III: Top 12 Most Cited Articles by Turkish Authors in JNSPG Journals

\begin{tabular}{ccccc}
\hline Ranking & Author & Issue & $\begin{array}{c}\text { Google Scholar } \\
\text { (Citations) }\end{array}$ & $\begin{array}{c}\text { Web of Science } \\
\text { (Citations) }\end{array}$ \\
\hline 1 & Türe and Yaşargil (48) & $90(4): 720-733,1999$ & 233 & 141 \\
\hline 2 & Mawad and Çekirge (31) & $96(3): 474-482,2002$ & 194 & 111 \\
\hline 3 & Türe and Yaşargil (49) & $92(4): 676-687,2000$ & 160 & 99 \\
\hline 4 & Altinors (5) & $93(1): 1-8,2000$ & 139 & 63 \\
\hline 5 & Ersahin (13) & $88(1): 57-65,1998$ & 117 & 61 \\
\hline 6 & Kaya (24) & $42(5): 580-584,1975$ & 97 & 76 \\
\hline 7 & Saatci (40) & $115(1): 78-88,2011$ & 76 & 42 \\
\hline 8 & Turgut (45) & $86(4): 714-718,1997$ & 76 & 35 \\
\hline 9 & Ozgen (32) & $50(3): 339-342,1979$ & 72 & 70 \\
\hline 10 & Erdem and Yaşargil (12) & $79(2): 256-265,1993$ & 68 & 45 \\
\hline 11 & Yavuz (52) & $107(1): 49-55,2007$ & 65 & 35 \\
\hline 12 & Yaşargil and Türe (51) & $101(5): 725-738,2004$ & 63 & 37 \\
\hline
\end{tabular}

Table IV: The Chronologic Distribution of Manuscripts Published in JNS by Turkish Authors

\begin{tabular}{ccc}
\hline Time Frame & JNS (Turkey) $\%$ & JNS (Abroad) $\%$ \\
\hline $1944-1969$ & 0 & 7.60 \\
\hline $1970-1979$ & 1.23 & 11.96 \\
\hline $1980-1989$ & 8.92 & 4.27 \\
\hline $1990-1999$ & 19.94 & 21.36 \\
\hline 2000-2009 & 46.13 & 38.46 \\
\hline 2010-2015 December included & 23.51 & 16.23 \\
\hline
\end{tabular}


following year. This journal was one of the first totally electronic journals (11).

Some milestones noteworthy in the history of JNS are as follows: a shift from single-to double-column pages was made in 1961 with publication of Volume 18 and the first Cumulative Index covering the initial 20 volumes was printed in 1964 (41).

During the editorship of Dr. William F. Collins (1984-1989) a computer tracking system for the journal was set to identify papers by author, subject matter (key words), and dates of receipt and acceptance. The system had also the capacity of preparing the annual statistics and generating tables. Manuscripts were entered on computer disks that were converted to type by the printer. The neurosurgical Biblioindex was discontinued (9). The JNSPG made it possible for all past issues to appear in full texts in the website "thejns.org" as of May 1,2009 (19).

The JNS is a peer-reviewed journal composed of a small group of a editorial board members of which are the primary reviewers. There are 11 members for the JNS, 12 members for JNS: Spine and 9 members for JNS: Pediatrics and outside reviewers are rarely needed (44).

The impact factor for JNS, JNS Spine, JNS Pediatrics and NF were $3.737,2.383,1.482$ and 2.105 respectively in 2014 (44).

\section{History of Acta Neurochirurgica}

AN is an outstanding European journal in the field of neurosurgery. It accepts for publication papers dealing with clinical neurosurgery, diagnosis and diagnostic techniques, surgery results, postoperative treatment and research. AN is the official organ of the European Association of Neurosurgical Societies (EANS) and it therefore publishes all announcements of the EANS and reports on the activities of its member societies. English is the only language of the journal.

AN is abstracted and indexed in Science Citation Index, Science Citation Index Expanded (Sci Search), Journal Citation, PubMed/Medline, Scopus, Google Scholar, Embase and 15 similar indexes. Its impact factor for 2014 is 1.77 .

The journal was found by Dr. Mario Milletti of Bologna and Dr. Volfram Sorgo of Innsbruck in 1950, in which year the first issue was published. The issues originally appeared at irregular intervals, but in 1996 issues were published continuously on a monthly basis $(36,39)$. Initially manuscripts were accepted in five languages; German, French, English, Italian and Spanish. We counted the articles on the basis of the language that they were published. Up to Volume 43 (1-2, March 1978) 1567 papers were published: 744 articles in German, 699 in English, 60 in French, 59 in Italian and five in Spanish.

In time, English became the only language of the journal (39). During the fourth meeting of many European Neurosurgical Societies in Prague in 1971, EANS was established. An important milestone in the history of AN was its acceptance as the journal as the official organ of EANS at Prague meeting.

\section{General Discussion}

A study has searched for articles defined as "citation classics" which meant articles that has been cited more than 400 times $(37,38)$. The study excluded nonclinical articles and found 106 such articles published in 28 different journals. Thirty articles $(28.3 \%)$ were published in Journal of Neurosurgery. The number of times articles were cited ranged from 402 to 4199 . Fifty-three articles were published since 1990 . The types of the articles were 29 randomized trials, 16 prospective

Table V: Types of Articles and the Proportion Published by Turkish Authors in Acta Neurochirurgica

\begin{tabular}{lccc}
\hline Type of article & Number & $\%$ & Information \\
\hline Case report & 109 & 32.05 & 92 animal, 1 microbiology, 1 electrophysiology \\
\hline Experimental & 94 & 27.64 & $\begin{array}{c}\text { r radiologic, 3 biochemistry, 3 genetic, } \\
\text { 1 electrophysiology }\end{array}$ \\
\hline Clinical series & 71 & 20.88 & 10 anatomic study, 2 pathologic findings, \\
\hline Letter to the editor & 26 & 7.64 & \\
\hline Cadaveric study & 15 & 4.41 & All intraoperative findings \\
\hline Technical note & 11 & 3.23 & \\
\hline Review article & 3 & 0.08 & \\
\hline EANS affairs & 3 & 0.08 & \\
\hline Anatomic study & 3 & 0.08 & \\
\hline Historical vignette & 2 & 0.058 & \\
\hline Literature survey & 2 & 0.058 & Data based literature search on a certain subject \\
\hline Immunohistochemical & 1 & 0.029 & \\
\hline
\end{tabular}


studies, 15 classification or grading systems, 17 reviews and the remaining 39 articles included case studies, case reports or technical notes.

A study by Wilcox et al. (50) reviewed four clinical pediatric neurosurgery journals. They examined the 100 most cited publications in the overall literature and the top 50 articles between 2002 and 2012. JNS: Pediatrics was one of the three journals where the most cited 50 articles were published. The authors concluded that an original paper in pediatric neurosurgery having a total citation count of 50 or more, and an average citation of 5 for each year or more can be considered as having high impact publication.

The second part of the previous study aimed to capture the 100 most cited articles in the overall literature and the top 50 articles from 2002 to 2012 . The 100 most cited articles appeared in 44 journals. Publication dates ranged from 1986 to 2008. The 50 most cited articles from 2002 to 2012 appeared in 31 journals. The conclusion was that an original paper related to clinical pediatric neurosurgery in a nonpediatric neurosurgical journal having a total citation count of 100-150 or more and an average citation count of 10-15 per year or more can be considered a high impact publication (25).

A retrospective bibliometric study using MEDLINE recording all publications between 1996 and 2009 by the first author affiliated with neurosurgical departments revealed a total number 53,425 articles composing $0.64 \%$ of all articles cataloged in MEDLINE (17).

The USA was the major contributor, followed by Japan. Turkey was one of the rapidly growing countries $(25.3 \pm 9.98 \% / y e a r$, $p<0.001)$. This performance has placed Turkey between $5^{\text {th }}$ through $10^{\text {th }}$ most productive in the world. Turkey was third in the number of case reports, sixth in all articles, seventh in the categories of review articles, general research and randomized clinical trial (RCT) sharing seventh place with Canada, and eight in RCTs.

Tekkök and Açıkgöz have conducted a search of publications from Turkey in European and American Neurosurgical journals between the years 1965 and 1990. They have noted the progress of Turkish publications and citations to those articles between the years 1965 and 1990 (43).

Arslantaş et al. (6) have reviewed the Turkish contribution to spine surgery literature and they have found that with respect to the published papers in JNS: Spine, articles originating from Turkey were second, sixth, fourth, third and fourth in number in 2000, 2001, 2002, 2003 and 2004 respectively.

Turkish neurosurgery had a late start in publishing articles in JNS. The JNS: Spine, the JNS: Pediatrics and NF have begun publication in 1999, 2004 and 1996 respectively. These dates correspond to growth of neurosurgery in the country and eventually Turkish contribution to JNS: Spine, JNS: Pediatrics and NF have been greater than contribution to JNS. (JNS 1.32\%, JNS: Spine 4.83\%, JNS: Pediatrics 2.59\%, NF $2.46 \%$ and overall contribution 1.94\%).

The ANS publishes more focused articles with each issue being devoted to a particular subject. The Turkish contribution to ANS is quite insignificant and more than half of this contribution came from Turkish scientists working overseas.

The top 10 papers published in AN and ANS by Turkish scientists according to citation ranking appear in Tables $\mathrm{VI}$ and VII.

According to the statistics of the Ministry of Health, there are 1904 accredited neurosurgeons in Turkey as of December 2015 and the country has a population of 78 million. The neurosurgical community is represented by three societies. The Turkish Neurosurgical Society, based in Ankara, was founded in 1989 and has 1500 members. The society is a member of EANS and World Federation of Neurosurgical Societies (WFNS).

The Nervous System Surgery Society was found in Istanbul in 2005 and has 190 members. The two societies organize annual congresses as well as several other scientific activities. Both publish journals in Turkish and in English.

The most recent neurosurgical society that was established in 2015 is called the "Turkish Neurosurgical Academy".

There are around 100 Neurosurgical Teaching Centers in Turkey at Universities and some state hospitals. The papers published in AN came from 75 different centers, although 39 centers contributed with only one or two articles. The distribution of this volume included 36 state Universities, 4 private Universities, 26 State teaching hospitals, 5 Military hospitals (two of them teaching centers) and 4 private hospitals. In 75 articles multiple centers were quoted as contributors whereas seven other articles involved overseas collaboration. Nine centers contributed over 10 articles; Ankara and Hacettepe Universities (both with 30 articles); Akdeniz University with 17 articles; Istanbul University Cerrahpasa School of Medicine (with 15 articles); Adnan Menderes University (with 14 articles); Gazi and Marmara Universities (both with 13 articles); Başkent University (with 12 articles) and Yıldırım Beyazıt State Hospital of Ankara (with 11 articles).

\section{- CONCLUSION}

All the above data and figures indicate both the successes and deficits of the Turkish Neurosurgical community with respect to contributions to international publications.

There has definitely been an overwhelming quantitative increase especially in the past two decades. The reasons for this progress may be summarized as:

a) Turkish Higher Education Council has stimulated scientific publication by raising the criteria of academic promotions.

b) There has been an enormous increase in the number of teaching departments, even to the degree of oversaturation. Consequently, the number of neurosurgeons has also increased. The standards of teaching centers are accordingly not so homogenous. Younger scientists have accelerated scientific activity and publication.

c) Turkish researchers' capacity for learning and writing English has shown widespread improvement. 
Table VI: Top 10 Most Cited Articles by Turkish Authors in Acta Neurochirurgica

\begin{tabular}{cccc}
\hline Number & Author & Article & Number of Citations \\
\hline 1 & Kalayci M. et al. (20) & $146(12): 1347-1354,2004$ & 102 \\
\hline 2 & Görgülü A. et al. (15) & $142(11): 1287-1292,2000$ & 95 \\
\hline 3 & Kilincer C. et al. (26) & $147(6): 587-594,2005$ & 88 \\
\hline 4 & Akalan N. et al. (2) & $142(1): 17-23,2000$ & 85 \\
\hline 5 & Açikbaş SC. et al. (1) & $144(5): 475-480,2002$ & 77 \\
\hline 6 & Pamir MN. et al. (33) & $147(11): 1121-1130,2005$ & 74 \\
\hline 7 & Turgut M. et al. (46) & $152(5): 749-761,2010$ & 70 \\
\hline 8 & Turgut M. et al. (47) & $148(10): 1033-1044,2006$ & 66 \\
\hline 10 & Bekar A. et al. (8) & $143(6): 533-536,2001$ & 63 \\
\hline
\end{tabular}

Table VII: Top 10 Most Cited Articles by Turkish Authors in Acta Neurochirurgica Supplement

\begin{tabular}{ccccc}
\hline Number & Author & Turkish Author & Article & Number of Citations \\
\hline 1 & Kanpolat Y et al. (21) & & $46: 67-78,1989$ & 42 \\
\hline 2 & Taya K et al. (42) & Gulsen S/2 ${ }^{\text {nd }}$ author & $102: 425-429,2009$ & 40 \\
\hline 3 & Marmarou A et al. (30) & Aygok G/3 ${ }^{\text {rd }}$ author & $95: 277-280,2005$ & 39 \\
\hline 4 & Pamir MN et al. (35) & & $98: 97-100,2006$ & 38 \\
\hline 5 & Kleindienst A et al. (27) & Eyüpoğlu Y/3 ${ }^{\text {rd } \text { author }}$ & $106: 247-250,2010$ & 35 \\
\hline 6 & Kanpolat Y et al. (22) & & $64: 88-91,1995$ & 25 \\
\hline 7 & Kanpolat Y et al. (23) & & $30: 363-366,1980$ & 25 \\
\hline 8 & Aygok G et al. (7) & Aygok G/1 & \\
\hline 10 & Pamir MN et al. (34) & & $85: 241-245,2005$ & 21 \\
\hline
\end{tabular}

d) Technologic developments have given researchers easy, rapid access to literature.

e) The increase in international relations and opportunities for working abroad -at least in temporary status- have also contributed to progress in Turkey.

In spite of this quantitative improvements there are areas of insufficiency and issues that require serious consideration. The impact factor and number of citations still need to be improved. The kind of articles should shift from case reports and clinic series to original experimental studies. This requires bigger budgets and -better- trained basic science researchers working in cooperation with clinicians. International collaboration should be promoted and supported. Multicenter prospective and meta-analytic studies in Turkey as well as international research projects with high scientific level need to be planned and achieved. Efforts to invite world famous faculty and young researchers for teaching purposes and project partnership should be enhanced.
Our study has the drawback of being limited to journals published by JNSPG and to AN. These journals are highly prestigious, very prominent, among those most commonly read and have high impact factors. They were chosen to represent North America and Europe. They reflect an idea about the literature in general and we hope that present study may pave the way for more comprehensive reviews in future.

\section{REFERENCES}

1. Acikbas SC, Akyuz M, Kazan S, Tuncer R: Complications of closed continous lumbar drainage of cerebrospinal fluid. Acta Neurochir 144(5): 475-480, 2002

2. Akalan N, Ozgen T: Infection as a cause of spinal cord compression: A review of 36 spinal epidural abscess cases. Acta Neurochir 142(1): 17-23, 2000

3. Alexander E Jr: Evolution of the Journal of Neurosurgery. $J$ Neurosurg 80: 762-766, 1994 
4. Alkan T, Korfali E, Kahveci N: Experimental subarachnoid haemorrhage models in rats. Acta Neurochir Suppl 83: 61-69, 2002

5. Altinors N, Bavbek M, Caner HH, Erdogan B: Central nervous system hydatidosis in Turkey: A cooperative study and literature survey analysis of 458 cases. J Neurosurg 93(1): 1-8, 2000

6. Arslantas A, Naderi S: The contribution of Turkish neurosurgeons to spine surgery literature. Turk Neurosurg 15(2): 45-51, 2005

7. Aygok G, Marmarou A, Young HF: Three-year outcome of shunted idiopathic NPH patients. Acta Neurochir Suppl 95: 241-245,2005

8. Bekar A, Korfali E, Dogan S, Yilmazlar S, Baskan Z, Aksoy $\mathrm{K}$ : The effect of hair on infection after cranial surgery. Acta Neurochir 143(6):533-536,2001

9. Collins WF: The Journal of Neurosurgery in the computer era. J Neurosurg 81: 147-149, 1994

10. Davey LM: John F. Fulton, M.D., and the founding of the Journal of Neurosurgery. J Neurosurg 80: 584-587, 1994

11. Eliason JAM: From manuscript submission to publication: A tour of the Journal of Neurosurgery Publishing Group. J Neurosurg 106: 717-722, 2007

12. Erdem A, Yasargil G, Roth P: Microsurgical anatomy of the hippocampal arteries. J Neurosurg 79(2):256-265, 1993

13. Ersahin Y, Mutluer S, Kocaman S, Demirtaş E: Split spinal cord malformations in children. J Neurosurg 88(1):57-65, 1998

14. Gokay H, Buck PC: Osteochondroma of the lumbar spine: Report of a case. J Neurosurg 12(1): 72-78, 1955

15. Gorgulu HM, Karadag O, Turaclar U, Tas F, Oztoprak I: Nitric oxide synthase inhibition attenuates vasoactive response to spinal cord stimulation in an experimental cerebral vasospasm model. Acta Neurochir 143(4): 383-390, 2001

16. Gunzburg R, Szpalski M, Aebi M: The impact factor: Publish, be cited or perish. Eur Spine 11 Suppl 1: S1, 2002

17. Hauptman JS, Chow DS, Martin NA, Itagaki MW: Research productivity in neurosurgery: Trends in globalization, scientific, focus, and funding. J Neurosurg 115: 1262-1272, 2011

18. Hirsch JE: An index to quantify an individual's scientific research output. Proc Natl Acad Sci USA 102:16569-16572, 2005

19. Jane JA: Bringing forth the old: Addition of legacy content to the Journal of Neurosurgery Publishing Group website, editorial. J Neurosurg 110: 819, 2009

20. Kalayci M, Cagavi F, Gul S, Yenidunya S, Acıkgoz B: Intramedullary spinal cord metastases: Diagnosis and treatment-an illustrated review. Acta Neurochir 146(12):13471354, 2004

21. Kanpolat Y, Deda H, Akyar S, Bilgic S: CT-guided percutaneous cordotomy. Acta Neurochir Suppl 46: 67-78, 1989

22. Kanpolat Y, Caglar S, Akyar S, Temiz C: CT-guided pain procedures for intractable pain in malignancy. Acta Neurochir Suppl 64: 88-91, 1995

23. Kanpolat Y, Onol B: Experimental percutaneous approach to the trigeminal ganglion in dogs with histopathological evaluation of radiofrequency lesions. Acta Neurochir Suppl 30: 363-366, 1980
24. Kaya U, Ozden B, Turker K, Tarcan B: Intracranial hydatid cysts-study of 17 cases. J Neurosurg 42(5):580-584,1975

25. Khan NR, Auschwitz T, McAbee JH, Boop FA, Klimo P Jr: Highly cited publications in pediatric neurosurgery: Part 2. Childs Nerv Syst 29: 2215-2228, 2013

26. Kilincer C, Asil T, Utku U, Hamamcioglu MK, Turgut N, Hiçdonmez T, Simsek O, Ekuklu G, Cobanoglu S: Factors affecting the outcome of decompressive craniectomy for large hemispheric infarctions: A prospective cohort study. Acta Neurochir 147(6): 587-594, 2005

27. Kleindienst A, Meissner S, Eyupoglu $Y$, Parsch $H$, Schmidt C, Buchfelder M: Dynamics of S100B release into serum and cerebrospinal fluid following acute brain injury. Acta Neurochir Suppl 106:247-250, 2010

28. Kuday C, Uzan M, Hanci M: Statistical analysis of the factors affecting the outcome of extradural haematomas: 115 cases. Acta Neurochir 131(3-4): 203-206, 1994

29. Laws RL Jr: The binding influence of the Journal of Neurosurgery on the evolution of neurosurgery. J Neurosurg 81: 317-321, 1994

30. Marmarou A, Saad A, Aygok G, Rigsbee M: Contribution of raised ICP and hypotension to CPP reduction in severe head injury: Correlation to outcome. Acta Neurochir Suppl 95: 277280,2005

31. Mawad ME, Cekirge S, Ciceri E, Saatci I: Endovascular treatment of giant and large intracranial aneurysms by using a combination of stent placement and liquid polymer injection. J Neurosurg 96(3): 474-482, 2002

32. Ozgen T, Erbengi A, Bertan V, Saglam S, Gurcay O, Pirnar T: Use of computerized tomography in the diagnosis of cerebral hydatid disease. J Neurosurg 50(3):339-342, 1979

33. Pamir MN, Ozduman K, Berilgen M, Kilic T, Ozek MM: Outcome determinants of pterional surgery for tuberculum sella meningiomas. Acta Neurochir 147 (11):1121-1130, 2005

34. Pamir MN: How to write an experimental research paper. Acta Neurochir Suppl 83: 109-113, 2002

35. Pamir MN, Peker S, Ozek MM, Dinçer A: Intraoperative MR imaging: Preliminary results with 3 Tesla MR sysytem. Acta Neurochir Suppl 98: 97-100,2006

36. Paterniti S: Commemoration of the centenary of the birth of Mario Milletti (1914-1959) co-founder of Acta Neurochirurgica. Acta Neurochir 157(5): 813-817, 2015

37. Ponce FA, Lozano AM: Highly cited works in neurosurgery. Part II: The citation classics. J Neurosurg 112:233-246, 2010

38. Ponce FA, Lozano AM: Erratum. Highly cited works in neurosurgery. Part II: the citation classics. J Neurosurg 120:1252-1257, 2014

39. Reulen HJ, Collman H: The beginnings of Acta neurochirurgica and the work of Fritz Loew, chief editor from 1958-1997. An historical vignette. Acta Neurochir 154:1311-1319, 2012

40. Saatci I, Geyik S, Yavuz K, Cekirge HS: Endovascular treatment of brain AVM's with prolonged intracranial Onyx injection technique- long term results in 350 consecutive patients with completed endovascular treatment. J Neurosurg 115(1):78-88, 2011

41. Schwartz HG: History of the Journal of Neurosurgery, 19651980. J Neurosurg 80: 939-940, 1994 
42. Taya K, Gulsen S, Okuno K, Prieto R, Marmarou CR, Marmarou A: Modulation of AQP4 expression by the selective V1a receptor antagonist, SR49059, decreases trauma-induced brain edema. Acta Neurochir Suppl 102:425-429, 2009

43. Tekkok IH, Acikgoz B: Publications from Turkey in European and American Neurosurgical Journals- A review of the facts. Turk Neurosurg 4: 106-110,1994

44. thejns.org $>$ about us

45. Turgut M, Benli K, Eryilmaz M: Secondary multiple hydatid cysts caused by intracerebral embolism of cardiac echinococcus- An unexceptional case of hydatidosis-case report. J Neurosurg 86(4):714-718, 1997

46. Turgut M, Ozsunar Y, Basak S, Guney E, Kir E, Meteoglu I: Pituitary apoplexy: An overview of 186 cases published during the last century. Acta Neurochir 152(5): 749-761, 2010

47. Turgut M, Turgut AT, Kosar U: Spinal brucellosis: Turkish experience based on 452 cases published in the last century. Acta Neurochir 148 (10):1033-1044,2006
48. Ture U, Yasargil DC, Al-Mefty O, Yasargil MG: Topographic anatomy of the insular region. J Neurosurg 90(4):720-733,1999

49. Ture U, Yasargil DC, Al-Mefty O, Yasargil MG: Arteries of the insula. J Neurosurg 92(4): 676-687, 2000

50. Wilcox MA, Khan NR, McAbee JH, Boop FA, Klimo P Jr: Highly cited publications in pediatric neurosurgery. Childs Nerv Syst 29(12):2201-2213, 2013

51. Yasargil MG, Ture U, Yasargil DC: Impact of temporal lobe surgery. J Neurosurg 101(5):725-738, 2004

52. Yavuz K, Geyik S, Pamuk AG, Koc O, Saatci I, Cekirge HS: Immediate and midterm follow-up results using an electrodetechable, fully retrievable SOLO stent system in the endovascular coil occlusion of wide-necked cerebral aneurysms. J Neurosurg 107(1): 49-55, 2007 